\title{
Behavioural Characteristics and the Marketing Implications of the Low Income Consumers
}

\author{
Nkanikpo Ibok Ibok ${ }^{1} \&$ Victoria Sunday Umana ${ }^{2}$ \\ ${ }^{1}$ Department of Marketing, University of Uyo, Akwa Ibom State, Nigeria \\ ${ }^{2}$ Department of Business Management, University of Uyo, Akwa Ibom State, Nigeria \\ Correspondence: Nkanikpo Ibok Ibok, Department of Marketing, University of Uyo, Akwa Ibom State, Nigeria. Tel: \\ 234-80-2355-3684. E-mail: nkanikpo@yahoo.com
}

Received: July 29, 2013

doi:10.5430/ijba.v4n5p73
Accepted: August 26, 2013

Online Published: September 6, 2013

URL: http://dx.doi.org/10.5430/ijba.v4n5p73

\begin{abstract}
Existing knowledge about the characteristics and marketing implications of the low income consumers have not been well articulated by managers and academics alike. Yet research has demonstrated the strategic benefits of this market in contributing to market share and return on investment. This paper begins by discussing the importance of this market by reporting the insights obtained in an exploratory research by reviewing the limited number of studies in this area, highlighting its nature and characteristics, drawing some specific implications and offering propositions to stimulate further research about the low income market.
\end{abstract}

Keywords: behavioural characteristics, marketing implications, low income market

\section{Introduction}

In recent years, the study of consumers with limited income access has become very popular. This is evidenced in the number of academic publications in the area (Knowledge Resources, 2011; Schonfeldt, Gibson and Vermenlen, 2010). While the interest in low income consumers is immense, it is quite clear that much of the knowledge and understanding about low income consumers are mixed or daunting. At least, there appears to be little research on the characteristics and marketing implications of this group of consumers. And although, the low income market is a viable and highly untapped market, Ibok (2011) had observed that the level of marketing attention given to this market is low if not neglected in organizational plan; but noted further that the success of any firm lies in its ability to see beyond today, particularly as the government at various levels are making effort to fight poverty and improve the living standard of an average consumer. This therefore, suggest that there is need for marketers to take special interest in understanding the behavioural characteristics of this market because they display specific and unique needs which must be traded with caution. Thus, Bilijon and Rousburg (2011) noted that understanding the behaviours of consumers who have limited access to income and live in rural or urban informal setting where infrastructure is limited, provides unique research challenges. The above scenario therefore has contributed to the paucity of literature and the existence of a number of gaps in the knowledge base of the low income market. First, from a theoretical perspective, the characteristic of this market is largely unclear and its theoretical underpinning is such that it is doubtful. Second, from a research perspective, it is not very clear why this market is often disregarded as unimportant. Little effort is made to understand the needs and expectations of the consumers in this market and as such it appears that there is no meaningful literature review that has considered this market from a broader organizational perspective.

In this paper, we attempt to present a balanced review of the behavioural characteristics of this market; because from the literature, there seems to be little understanding of the unique characteristics of this market (Prahalad, 2010; Adkins and Ozanne, 2005; Soyibo, 2007). Accordingly, Van, Britz and Myburgh (2002) concluded that marketing to the low income group in the society has been poorly understood and there is a high degree of confusion about its marketing implication. Thus, from a meta-analytical perspective, the issue of consolidating knowledge gathered along different applications raises some basic questions as to whether marketing to the poor has any coherent knowledge framework and what meaning does it have to marketers? 
Therefore viewing from this perspective, we contend that in order to better understand the above mentioned issues; a systematic review of relevant literature is needed so as to guide future marketing decisions. While there have been several review articles on people living in poverty that is published recently, there appears to only partially address the conceptual issues and do not address marketing implications issues at all. For example; Ellis (2009) focuses on the definition of poverty. Lee (2002), Martins and Groom (2003) and Adeji and Praise (2006) take a strategic management dimension of marketing to the low income group. Likewise, Ebenezer (2006) provides a reasonable overview of the poverty literature. Hence, some of the reviews made by scholars on low income consumers are narrowly based without specific marketing underpinnings. For example; Tom and Akpan (2011) review is focused on the overarching Philosophy of the rural poor whilst Davis's (2005) review is focused on the consumer behaviour literature. This among other considerations suggests that there does not appear to be a review that has considered this specific and unique market from a broader organizational marketing perspective. Therefore, as far as conceptual, methodological and theoretical issues are concerned, none of the reviews appear to have systematically examined the marketing implications of marketing to the poor. (Ibok 2011).

The section which follows provides details of how the review was conducted. First, the literature review is presented, which is a discussion of the basic issues pertaining to consumers with little access to income. Leading from this discussion, future research possibilities are proposed. The paper concludes by summarizing the key issue, highlighting the contributions of this paper to the body of knowledge and identifying the marketing implications for practitioners and researchers.

\section{Literature Review}

In order to set the research agenda for this paper, the LSM classification as developed by South African Research foundation was used as the benchmark for discussion. This is because the LSM has become a very popular and widely used marketing research tool. The LSM index divides the consumer market into 10 relatively homogeneous groups; and it is used in measuring wealth based on the standard of living of the people rather than income, education, occupation or any other parameter (Haupt, 2006). Using this index profile therefore, households that fall into LSM groups from one to four are regarded as poor or people with less access to income, thus, they are mostly described as poor or impoverished (Martins, 2006).

In Nigeria, this group constitutes not less than 54 percent of the population (Akpan, 2010) and is a large consumer group for any purposeful targeting. However, Prahalad, (2010) observed that this category of the consumer market is often disregarded as unimportant because of their limited income access and hence they are often exploited using low cost substandard products. Gan and Viswaratha (2008) in their submissions noted that the unique nature of this poor consumers are often disregarded but Prahalad (2010) Cautions that this emerging market is worth targeting because they constitute a significant market and thus represent an engine of economic innovation, vitality and growth,

Accordingly, Cant et.al (2007) and Statistics South Africa (2010) attempts to describe the composition of this market as consisting of consumers with low level of literacy, whose average income is also low, lived mostly in rural setting and mostly informal settlements and describe their housing structures to be mostly rural huts, generally home made from mud or clay. Further complicating their marketing opportunity it the fact that English is not their first language (statistics South Africa, 2010). Because of the nature and composition of these classes of consumers, their low sophistication level, is imposing difficult challenges to marketing management amidst sizeable market potential which should not be left untapped.

However, the low level of income, education and communication barriers with this category of consumers potentially limits marketing effectiveness, which may necessitate alternative marketing solution.

The marketing literature on the rural poor provides a useful background on this consumer's trait and its relevance. Dim (2004) stated that there are five dimensions by which consumers with limited income access can be identified to include:

(a) Consumption pattern

(b) Dressing pattern

(c) Housing pattern

(d) Living standard and

(e) Location or habitation

Mitchel and Dennis (2006) offer experiential evidence of the behaviours of these classes of consumers by noting its predictive characteristics. They also provide an excellent review of the psychological disposition of these consumers 
in various cognitive functional areas. Additional evidence of the composition and characteristics of these class of consumers is offered by Lec (2005); Mauren (2007); little (2005); and Bloch (2006).

The fact that these consumers sort across quality grades on differences of their behavioural predisposition is not new in the literature (Prahalad, 2010; Martins, 2010). A number of theoretical analysis have considered the marketing outcomes of relating with these consumers and one consistent findings across the literature is that consumers with different social dispositions select products differently irrespective of their income level.

There are numerous examples from around the world of organizations benefiting from marketing to the less income consumers (see Adkins and Ozanne, 2005; Van, Britz and Myburg, 2002, Gau and Viswaratha, 2008). The significant contributions of consumers in promoting sustainability of business really warrant investigation in order to enhance continuous patronage which will eventually result in the better performance of the micro economic units. It is however noted that one of the ways through which businesses can do well is to better understand their customers' behaviour.

Given that there is a high level of poverty in Nigeria, which is around 54.0 percent (CBN, 2009), these set of consumers tend to be highly price sensitive; yet they are very large. Thus, the combined purchasing power within this market justifies why marketers should be interested in this market. This is an issue of a major concern in this paper, since many businesses are found located in the town with very few interested in the rural population, whose majority are impoverished.

Given the involvement of various individuals (the government, NGOS and other organizations) in alleviating poverty, targeting these customers vigorously can be viewed as a marketing approach to achieving desired lifestyle changes. In the observation of Ologun (2004) there are two major qualities that characterize people living in poverty, namely; these customers have limited access to income and secondly they live in mostly rural informal settlements where access to infrastructural facilities are lacking. Because of their unique nature, they seem to be swifter and more agile and so respond positively or negatively to emerging market trends. Davis (2005) confirmed this assertion by adding that the general attitudes and characteristics of this category of customers is how to survive, with little or no spirit of trying any innovation. Ogunbanjo (2007) in his survey of the rural poor reports that inspire of the large number of poverty alleviation programmes in Nigerian, most of the customers, particularly the rural poor are still living in relatively low cost, substandard quality of life. Akan and Esua (2007) corroborates this by stating that management that can articulate and consistently conceptualize the operational variables of the poor will be successful particularly in encapsulating the customers desires for accelerated market leadership.

Accordingly, behavioural diagnosis of the poor is a vital consideration for any marketing success. Behavioural diagnosis denotes that customers be understood. Recent studies show that organizations can increase their market competitiveness only by coordinating all functional parts of the market without leaving any part to the competitor (Jones, 2006; Saeed, 2006 and Okorafor, 2008). The composition of this market encompasses competitive intensity; and varied marketing strategy (Anderson, 2004; Brown, 2005; Ashika, 2005 and Hills, 2007). The above studies suggest that firms operating in a highly competitive environment must take a flexible approach so that they can adapt and possess the capability to respond to new market and competitive behaviours and deploy critical resources and adopt more diverse strategic options to compete effectively. Because firms are more likely to face challenging and unique situations in this market, then market orientation should be more useful. Previous research by Odon (2008) reveals that although there is high market potentials in the poor, there is minimal efforts made in understanding the needs of these customers. As a result, this market has remained largely untapped or sometimes underserved because it is regarded as unimportant due to their limited income. But Prahalad, (2010) had cautioned that any business that can overcome this skepticism will realize that this market offers viable business opportunities.

Accordingly, Biron (2003) observed that consumers with limited income access are mostly people who have low level literacy, they have no formal education, and their average income per household is low. English Language is not their first language, they mostly reside in informal rural settlements, their housing structure is mostly rural huts and that they are very sensitive to price and so they consider affordability as the most important buying criterion.

\section{Emerging Issues}

Building strong markets is of increasing importance for many firms. However, little is known about how to build a strong market from the relative poor (Asika 2006). One of the most important investments any firm can do is the investment in cultivating hybrid customers. Although it would invite little suspicion to claim that the low income market plays a crucial role in building strong firms, to date no research has attempted to explore the unique opportunities prevalent in this market (Martins 2008). So far, consumer research has focused on exploring the nature 
and value of significant customers (Martins, 2008; Ibok, 2011) and developing measures to attract it (Hurt, 2008). But the less affluence consumers have suffered neglect in organizational plan. ( Prahalad, 2011; Ibok, 2011) .

Given the fact that the low income market has become a major strategic priority for many focused strategies, it is becoming increasingly valuable to identify how targeting these customers could drive competitiveness and enable firms to enjoy some market advantage. The major issue here is to improve competitiveness through larger market coverage that could enhance better business experience where hope is lost and competitors seem not to have interest.

Investment in the low income market will in turn strengthen positive loyalty (Dean, 2002; Gordon, 2004; and Bell, 2006). Strong positive association derived from customer behavioural characteristics can enhance a firm's competitiveness in the market (Ibok, 2011).

A review of both consumer behaviour literature and the strategic literature suggest that the customer is an indispensable ally for any meaningful strategy. The central tenet of this paper is that having interest in all markets irrespective of their perceived value would lead to overall competitive advantage. Hence, many previous studies on the power of a firm have been observed to emanate from market knowledge capacity. Therefore, our interpretation and review of the extant literature on the low income market is instructive based on the following reasons; first, the customer loyalty framework states that loyalty is an outcome of perceived market satisfaction second, perceived market interest has been advocated as a crucial source of market power. Finally, low income market can also be good sources of pursuing alternative segments. Therefore, the role and knowledge of the low income market has become apparently more important.

\section{Managerial Implications}

This paper has several managerial and theoretical implications. The general implication is that managers should be aware of the composition and understand the behavioural characteristics of the low income market. More specifically, the long term investment in this market and orientation of the low income market can play a critical role in sustaining competitive advantage. This means setting long-term goals giving emphasis to cultivating these customers, while devoting time, efforts and resources could make the firm to be more effective and efficient in the market. The low income market potential should be a major concern for marketers today. By maintaining a responsive relationship with this market, firms can have a golden opportunity and a chance to turn a loss market into an asset when the market eventually matures. The key is to view this market as important opportunities more than as problems.

Finally, marketers should be proactive in findings best approaches in reaching this market by communicating an appropriate, targeted message via social media along with traditional methods of communicating with target consumers in a typical, informal, rural Language.

More specifically managerial attention is needed in understanding the market characteristics. First, the market considers affordability of a product as a necessary precondition for purchase and so price is a major determining factor in product patronage. Secondly, because this market has limited income and can therefore not afford to be disappointed by a product failure resulting from poor quality, consumers in this market would always place much emphasis on product quality especially when it goes with guarantee. Thirdly, of utmost importance to note is the convenience of access to the company's product or service. Therefore, convenience of access is an important consideration to the market. Finally, because of this markets limited income access, they would always be very skeptical in brand selection for fear of making wrong decisions and so they go after known brands. Most importantly is the method of communicating with this market since their primary language is not English, an alternative communication like the use of vernacular is necessary in reaching the market, while the use of traditional media is also advocated.

\section{Theoretical Implications}

The purpose of this paper was to focus on how best the characteristics and the marketing implications of the low income market could be understood in order to attract academic attention in the behavioural literature as a possible means of contributing to consumer behaviour theory building. On the basis of a qualitative analysis, we determined that low income market could be interpreted, understood and approached in different ways. This understanding indicates the importance of looking at the specific characteristics of this market before targeting. The implications for consumer behaviour theory are two-fold. First, the combined purchasing effect of this market needs to be reconsidered, because the organization's neglect of these customers is an example of badly treated customer relationship which negates marketing theory. Secondly, the discovery of customer heterogeneity and the firm's ability to carefully target the customer base is indicative of porous strategies. Research is therefore needed to further 
explore the impact of the low income market on a firm's investment portfolio analysis, amidst relative contribution to market share and profit margin.

\section{Summary and Conclusion}

In summary, one important lesson for business is that they should not ignore the low churn customer segment because they can migrate up in value segment and if they don't understand this market segment and target it as appropriate, then the likelihood is that they may lose a great deal of value, thus giving opportunity to competitors. Appropriate use of the right marketing strategies can enhance business planning. Therefore, using the right communication and offers at the right time would create the needed customer value over time. However, the major insights gained from this expository paper suggest a conceptual model that will hopefully spawn academic and scholarly enquiry and serve as a framework for future research. Such research should shed more light on the marketing operations that best fit the sensitivities of the low income segment in the society.

\section{References}

Adeji, C.O., \& Prasie, K. (2006). Explaining the best marketing approach in the rural setting. Journal of Empirical and Applied Management Research, 16(4), 116-204.

Adkins, N., \& Ozanne, J. (2005). The Low literate Consumer. Journal of Consumer Research, 32(1), 93-105. http://dx.doi.org/10.1086/429603

Akan, J.A., \& Esua, W.R. (2007). Building a strong market against competition: some strategic considerations. Journal of Behavioural Studies, 6(8), 215-235.

Akpan, V.A. (2010). Factors that determine consumers choice in selecting consumer goods. Strategic Management Journal, 5(6), 120-132.

Anderson, B.J. (2004). Business Performance: Integrating customer focus across the firm. Research Journal in Accounting and Finance, 3(5), 201-220.

Ashika, G.S. (2005). Revisiting the low segment market. Journal of Agricultural Economics, 30(2), 333-342.

Bell, O.T. (2006). The impact of customers size on performance of manufacturing firms. Quarterly Review of Small Business Management, 3(4), 70-82.

Biron, J.S. (2003). Marketing Performance in the low income market: An empirical review. Journal of Economics and Administrative science, 3(4), 171-184.

Bloch, D.V. (2006). Strategies in a dynamic market place. Journal of Resources Management, 4(6), 214-228.

Brown, W.B. (2005). The customer as a measure of marketing productivity and performance. Journal of Marketing Science, 4(3), 116-124.

Cant, M.C., Strydom, J.W., Joostle, C.J., \& du. Plessis, P.J. (2007). Marketing Management (5 ${ }^{\text {th }}$ ed.). Cape Town: Juta and Co.Ltd.

Central Bank of Nigeria. (2009). Statistical Bulletin, 40(2).

Davis, S. R. (2005). Factors influencing consumption among bottom line consumers. Journal of Social Behaviour, 4(16), 121-130.

Dean, H.D. (2006). An impact assessment of the increasing incidence of poverty in Nigeria. Journal of Social Development, 22(2), 112-131.

Ebenezer, S.A. (2006). Promotion and Marketing Communications in an informal market. Journal of Marketing Research, 26(1), 216-224.

Ellis, V.J. (2009). A re -examination of the determinants of customer satisfaction among the poor. Journal of Marketing, 4(2), 7-19.

Gau, R., \& Viswamatha, M. (2008). The retail shopping experience of low literate consumers. Journal of Research in Consumer Behaviour, 15, 1-8.

Gau, W.D., \& Viswaratha, L.D. (2008). Investigating the buying characteristics of the Less Income Consumers. Journal of Marketing Research, 14(2), 76-90.

Gordon, F.D. (2004). Fallacies about the poor consumers and the marketing challenge. Review of Economics and Social Science, 25(2), 331-340. 
Haupt, P. (2006). The SAARF Universal Living standard measure (SULSM):12 years of continuous development. South African Advertising Research Foundation. Retrieved Jan. 13, 2009, from http:www.saarf.co.za

Haut, O.I. (2008). Challenges of targeting the rural poor: some marketing implications. Economic and Business Review, 6(1), 67-82.

Hills, F.O. (2007). Low income consumers: a review of the literature of marketing theory and of selected applications. Journal of Business and Economies, 27(2), 172-225.

Huchzermeyer, M., \& Karam, A. (2006). Informal settlements: A perceptual challenge? Cape Town: UCT. Press.

Ibok, N. I. (2011). How much does consumer matter? Journal of Consumer Research, 12(4), 167-186.

Jones, G.A. (2006). Problems and strategies in rural marketing. Journal of Economics and Management, 4(2), 62-80.

Knowledge Resources. (2011). Marketing to low Income consumers. Biz community. Retrieved March 16, 2011, from https/www.bizcommunity. co.za/Article/196/423/57760.html

Lee, M.P. (2005). Marketing annidst poverty. Journal of research in international Business, 6(10), 88-97.

Little, H.M. (2005). Navigating in a promising market: Advice to management. Academy of Business Journal, 6(4), 196-218.

Martins, J.H. (2010). Household cash expenditure by living standards measure group. J.Fam.Eco. Consum. Sci., 34(2006), 1-9.

Martins, K. J., \& Groom, N.S. (2003). Development of a customer satisfaction index model. Journal of Consumer Marketing, 16(5), 51-72.

Mauren, W.E. (2007). The Low income consumers: a study of their behavioural characteristics. Journal of Finance and Management, 13(1), 71-97.

Mitchel, C., \& Dennis, L.D. (2006). Marketing strategies in a growing market: A case study of the rural poor. Journal of Business, 62(2), 42-54.

Odon, J.L. (2008). Your power is in your consumers: An analysis of dynamic relationship. Journal of tropical Issues, 71(2), 139-143.

Ogumbanjo, C.L. (2007). Studies on low income consumers. Academic Digest, 1(1), 5-15.

Okorafor, A.A. (2008). The Theory of competitive advantage: Implications for strategy formulation. Journal of Management, 16(4), 171-180.

Ologum, V.P. (2004). A market contingent perspective of the relative poor. Journal of Social Sciences, 8(2), $102-114$.

Prahalad, C.K. (2010). The fortune at the Bottom of the pyramid: Eradicating poverty through profits (5 ${ }^{\text {th }}$ ed.). New Jersey: Pearson Education.

Saeed, N.A. (2006). Assessing the profit potential of the relative poor. Journal of Marketing Science, 21(7), 291-298.

Schonfeldt, H.C., Gibson, N., \& Vermeulem, H. (2010). The possible impact of inflation on nutritionally vulnerable households in a developing country using South Africa as a case study. Nutritional Bulletin, 35(3), 254-267. http://dx.doi.org/10.1111/j.1467-3010.2010.01837.x

Soyibo, W.J. (2007). Concentrating on the rural poor: An idea for emergency economic programme. CTLReview, $6(2), 18-26$.

Statistics South Africa. (2010). General Household Survey 2009. Statistics Release, 318.

Tom, A. P., \& Akpan, I. N. (2011). Real Marketing appeals: An investigation of the rural poor. Journal of International Business, 34(2).

Van-Wyk, J., Britz, T.J., \& Myburg, A.S. (2002). Arguments supporting kefir marketing to the low income urban African population in South Africa. Agrek, 41(1), 43-62. http://dx.doi.org/10.1080/03031853.2002.9523585 